\title{
Impact Analysis of Temperature Data on the Increase in the Count of Infected Cases of COVID 19
}

\author{
Parag Verma, Uttaranchal University, Dehradun, India \\ (iD) https://orcid.org/0000-0002-3201-4285 \\ Ankur Dumka, Graphic Era University, Dehradun, India \\ Anuj Bhardwaj, Chandigarh University, India \\ Alaknanda Ashok, College of Technology, G. B. Pant University of Agriculture and Technology, India \\ Mukesh Chandra Kestwal, Atal Incubation Center, EMPI, New Delhi, India \\ Praveen Kumar, Yuvayana Tech and Craft Pvt. Ltd., India
}

\begin{abstract}
There was an outbreak of pneumonia in the month of December 2019 in Wuhan, China that spread with a rapid rate throughout the country and shook the world by spreading across the globe causing many deaths due. This disease is confirmed by means of molecular method as a novel coronavirus and was named as 2019 novel coronavirus (2019-nCoV) in its initial stage; however, on February 11, 2020, World Health Organization (WHO) renamed this disease COVID-19, which means corona virus disease. COVID-19 has impacted nearly the entire world, affecting more than 100 countries including India. The Coronavirus Study Group consisting of the International Committee on Taxonomy of Viruses renamed this virus, which was provisionally named 2019-nCoV, as severe acute respiratory syndrome coronavirus-2 (SARS-CoV-2). This nomenclature is based on taxonomy, phylogeny, and established practice. As on March 2020, WHO has confirmed 692,575 number of cases of COVID-19 with 33,099 deaths, which are distributed across the globe: Western Pacific region with 103,775 confirmed cases with 3,649 deaths; European region with 392,757 number of confirmed cases with 23,962 deaths; South East Asia region with 4,084 confirmed cases with 158 deaths; Eastern Mediterranean region with 46,392 confirmed cases with 2,813 number of deaths; America region with 142,081 confirmed cases with 2,457 deaths; African region with 3,486 confirmed cases with 60 deaths. This paper focuses on these areas and regions and tries to find establish the relationship between numbers of deaths and number of cases with respect to the temperature. This paper takes the study of specific areas around the world and also the case study of India to study the effect of temperature on the rise of and death due to COVID-19 virus.
\end{abstract}

\section{KEYWORDS}

Coronavirus, COVID-19, Data Normalization, Effective Reproductive Number, Temperature 


\section{BACKGROUND}

Our paper study is based on the background that there is reporting in the early stage of COVID-19 that the virus spread and rise varies with temperature (Kim et al., 2016; Chen et al., 2019). We had taken temperature parameters of top 15 affected countries and tries to find our result with temperature parameters and in order to set up relationship between temperature and the rise and spread of this virus (Lancet 2020; Corman et al., 20230). We collected the data of top 15 affected countries along with India for month of January, February and March as (Tables 1-2 and Figure 1).

Table 1. Sample data with temperature and COVID 19 confirmed counts per week from January 23, 2020 to March 27, 2020

\begin{tabular}{|c|c|c|c|c|c|c|c|c|c|c|c|c|c|c|c|c|c|}
\hline \multirow{2}{*}{18.02 .20} & $\mathrm{CC}$ & 74211 & 3 & 13 & 2 & 16 & 0 & 12 & 0 & 9 & 31 & 0 & 0 & 1 & 8 & 0 & 3 \\
\hline & $\mathrm{T}\left({ }^{\circ} \mathrm{C}\right)$ & 10 & 16 & 14 & 13 & 8 & 13 & 11 & 10 & 10 & 2 & 8 & 11 & 9 & 5 & 8 & 25 \\
\hline \multirow{2}{*}{11.02 .20} & $\mathrm{CC}$ & 44386 & 3 & 12 & 2 & 16 & 0 & 11 & 0 & 8 & 28 & 0 & 0 & 1 & 7 & 0 & 3 \\
\hline & $\mathrm{T}\left({ }^{\circ} \mathrm{C}\right)$ & 11 & 18 & 13 & 15 & 7 & 1 & 9 & 11 & 7 & 13 & 6 & 8 & 7 & 2 & 5 & 21 \\
\hline \multirow{2}{*}{04.02 .20} & $\mathrm{CC}$ & 23707 & 2 & 11 & 1 & 12 & 0 & 6 & 0 & 2 & 16 & 0 & 0 & 1 & 4 & 0 & 3 \\
\hline & $\mathrm{T}\left({ }^{\circ} \mathrm{C}\right)$ & 1 & 18 & 18 & 20 & 7 & 11 & 9 & 13 & 9 & 3 & 7 & 10 & 6 & 2 & 1 & 20 \\
\hline \multirow{2}{*}{28.01 .20} & $\mathrm{CC}$ & 5509 & 0 & 5 & 0 & 4 & 0 & 4 & 0 & 0 & 4 & 0 & 0 & 0 & 2 & 0 & 0 \\
\hline & $\mathrm{T}\left({ }^{\circ} \mathrm{C}\right)$ & 6 & 13 & 8 & 12 & 9 & 8 & 8 & 9 & 7 & 11 & 6 & 6 & 7 & 1 & 2 & 19 \\
\hline \multirow{2}{*}{23.01 .20} & $\mathrm{CC}$ & 643 & 0 & 1 & 0 & 0 & 0 & 0 & 0 & 0 & 1 & 0 & 0 & 0 & 0 & 0 & 0 \\
\hline & $\mathrm{T}\left({ }^{\circ} \mathrm{C}\right)$ & 8 & 15 & 6 & 10 & 6 & 5 & 3 & 2 & 8 & 10 & 6 & 6 & 4 & 2 & 3 & 18 \\
\hline \multicolumn{2}{|c|}{ 逗 } & 莺 & 䔍 & $s$ & 苇 & 氙 & $\underset{\Xi}{\Xi}$ & 芯 & 宽 & 㲵 & 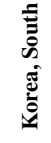 & 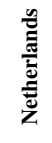 & 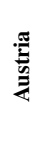 & 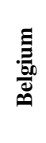 & 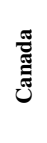 & $\stackrel{\vec{z}}{\vec{b}}$ & 舀 \\
\hline \multicolumn{2}{|l|}{ S.N } & 1 & 2 & 3 & 4 & 5 & 6 & 7 & 8 & 9 & 10 & 11 & 12 & 13 & 14 & 15 & 16 \\
\hline
\end{tabular}

Table 2. Sample data with temperature and COVID 19 confirmed counts per week from January 23, 2020 to March 27, 2020

\begin{tabular}{|c|c|c|c|c|c|c|c|c|c|c|c|c|c|c|c|c|c|}
\hline \multirow{2}{*}{ 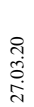 } & $\mathrm{CC}$ & 81661 & 74386 & 65778 & 49515 & 37323 & 27017 & 25600 & 10897 & 9640 & 9137 & 6438 & 5588 & 4937 & 3251 & 3084 & 657 \\
\hline & $\mathrm{T}\left({ }^{\circ} \mathrm{C}\right)$ & 13 & 17 & 12 & 10 & 18 & 15 & 13 & 12 & 13 & 16 & 13 & 17 & 13 & 9 & 9 & 26 \\
\hline \multirow{2}{*}{ 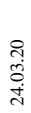 } & $\mathrm{CC}$ & 81591 & 69176 & 53740 & 39885 & 32986 & 24811 & 22622 & 9877 & 8164 & 9037 & 5580 & 5283 & 4269 & 2790 & 2863 & 536 \\
\hline & $\mathrm{T}\left({ }^{\circ} \mathrm{C}\right)$ & 18 & 10 & 12 & 15 & 10 & 15 & 13 & 24 & 15 & 18 & 11 & 8 & 12 & 5 & 5 & 31 \\
\hline \multirow{2}{*}{ 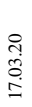 } & $\mathrm{CC}$ & 81058 & 31506 & 6421 & 11748 & 9257 & 16169 & 7715 & 2700 & 1960 & 8320 & 1711 & 1332 & 1243 & 478 & 1463 & 142 \\
\hline & $\mathrm{T}\left({ }^{\circ} \mathrm{C}\right)$ & 21 & 18 & 17 & 16 & 16 & 20 & 15 & 18 & 13 & 11 & 12 & 13 & 14 & 7 & 12 & 27 \\
\hline \multirow{2}{*}{ 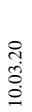 } & $\mathrm{CC}$ & 80887 & 10149 & 959 & 1695 & 1457 & 8042 & 1794 & 491 & 384 & 7513 & 382 & 182 & 267 & 79 & 400 & 56 \\
\hline & $\mathrm{T}\left({ }^{\circ} \mathrm{C}\right)$ & 11 & 17 & 21 & 22 & 9 & 17 & 15 & 7 & 15 & 10 & 11 & 12 & 12 & 11 & 4 & 25 \\
\hline \multirow{2}{*}{ 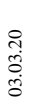 } & $\mathrm{CC}$ & 80261 & 2502 & 118 & 165 & 196 & 2336 & 204 & 56 & 51 & 5186 & 24 & 21 & 13 & 30 & 32 & 5 \\
\hline & $\mathrm{T}\left({ }^{\circ} \mathrm{C}\right)$ & 7 & 13 & 17 & 14 & 7 & 12 & 9 & 8 & 9 & 11 & 8 & 11 & 7 & 3 & 2 & 26 \\
\hline \multirow{3}{*}{$\begin{array}{l}\text { त्र } \\
\text { dे } \\
\text { पे }\end{array}$} & $\mathrm{CC}$ & 77754 & 322 & 51 & 6 & 17 & 95 & 14 & 1 & 13 & 977 & 0 & 2 & 1 & 11 & 0 & 3 \\
\hline & $\mathrm{T}\left({ }^{\circ} \mathrm{C}\right)$ & 9 & 17 & 12 & 18 & 11 & 12 & 11 & 12 & 8 & 8 & 10 & 17 & 10 & 3 & 0 & 25 \\
\hline & & 1 & 2 & 3 & 4 & 5 & 6 & 7 & 8 & 9 & 10 & 11 & 12 & 13 & 14 & 15 & 16 \\
\hline
\end{tabular}




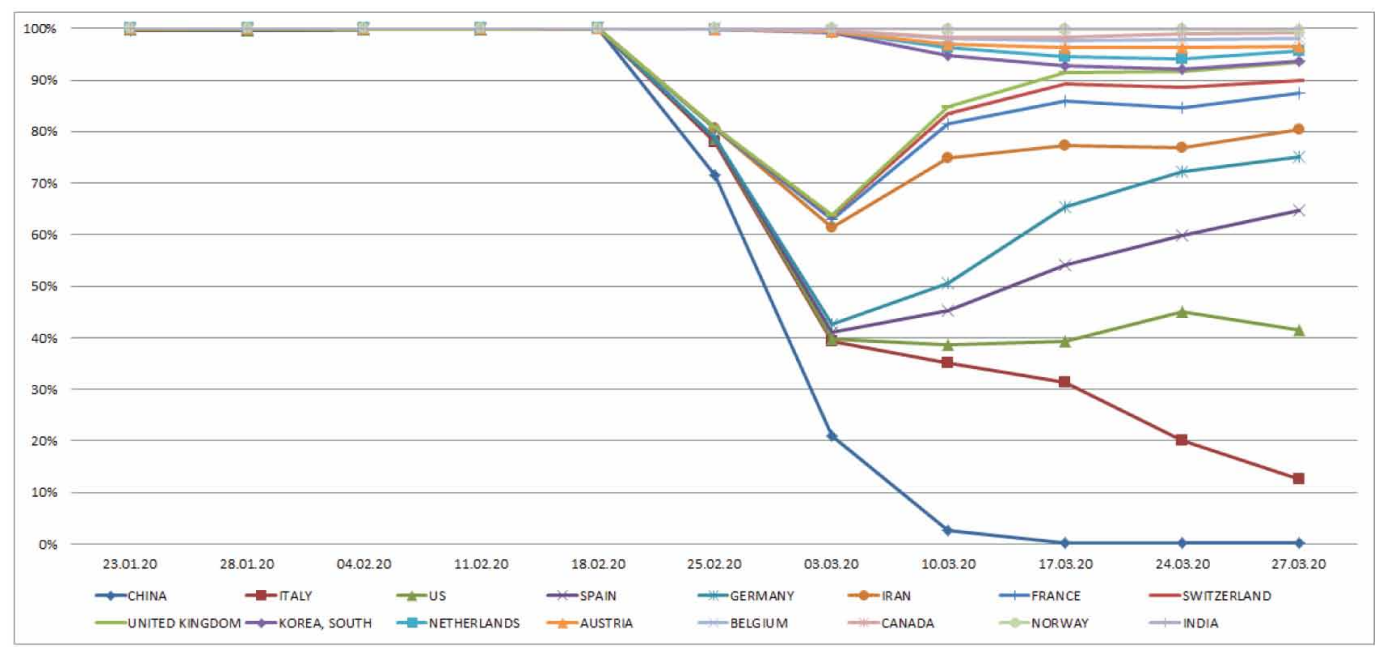

Now this data is being analysed with the data of the confirmed infected cases of COVID-19 at different countries mentioned above in order to find the relationship of COVID-19 with temperature and analysing the data (Guan et al., 2020; Bai et al., 2020). The above data consists of temperature on different dates (trying to cover maximum seven days interval) in the month of January, February and March and the number of confirmed cases in the subsequent year which gave us the data of the number of confirmed cases in subsequent days of the month suffered and confirmed for COVID-19 epidemic (Beck et al., 2020; Steel 2011). This data help us to understand the relationship between temperature and number of cases spreading in these countries with COVID-19 epidemic which help us to maintain a relationship between COVID-19 and temperature that weather temperature is really a parameter for rise or spread of COVID-19.

\section{DATA PRE-PROCESSING}

The scale and distribution of the collected data drawn from the domain differ for both the input variables. Due to the difference in the scales across the input variables for examples weather temperature $\left({ }^{\circ} \mathrm{C}\right)$ and COVID 19 confirmed number of counts (for example hundreds and thousands) that in turn may mean the input variables having different scales. Differences in the scales across input variables may increases the difficulty of the problem being modelled. Therefore, data analysis requires data scaling methods. For applying data scaling research used data normalization and standardization methodologies are as follows.

\subsection{Data Normalization}

Data normalizing is a variable that most frequently means dividing by a norm of the variable. It also often refers to rescaling by the minimum and range of the vector, to make all the elements lie between 0 and 1 thus bringing all the values of numeric columns in the dataset to a common scale. This scaling method requires minimum and maximum observable values. For normalization the data input variables following formula applied:

$$
X_{\text {norm }}=0.847 \times\left(\frac{\left(X_{i}-X_{\min }\right)}{\left(X_{\max }-X_{\min }\right)}\right)+0.1
$$


where, $X_{i}$ denotes the specific value of the variable, $X_{\max }$ denotes the maximum value of the variable dataset, $X_{\min }$ denotes the minimum value of the variable dataset.

\subsection{Data Standardization}

Data standardization is a process of rescaling the distribution of dataset values so that the mean of the observed values is 0 and the standard deviation is 1 . This data scaling method requires average and standard deviation value of the observable dataset. For standardizing the data input variables following formula applied:

$$
X_{\text {stnd }}=\left(\frac{\left(X_{i}-\text { Average }\right)}{s \tan \text { dard_deviation }}\right)
$$

After applying the data normalization and standardization the collected data is graphically analysed, results are presented in Figure 2. At some points temperature provide significant impacts on the COVID 19 infected cases worldwide.

Figure 2. COVID 19 infected confirmed cases counts vs. Temperature per day

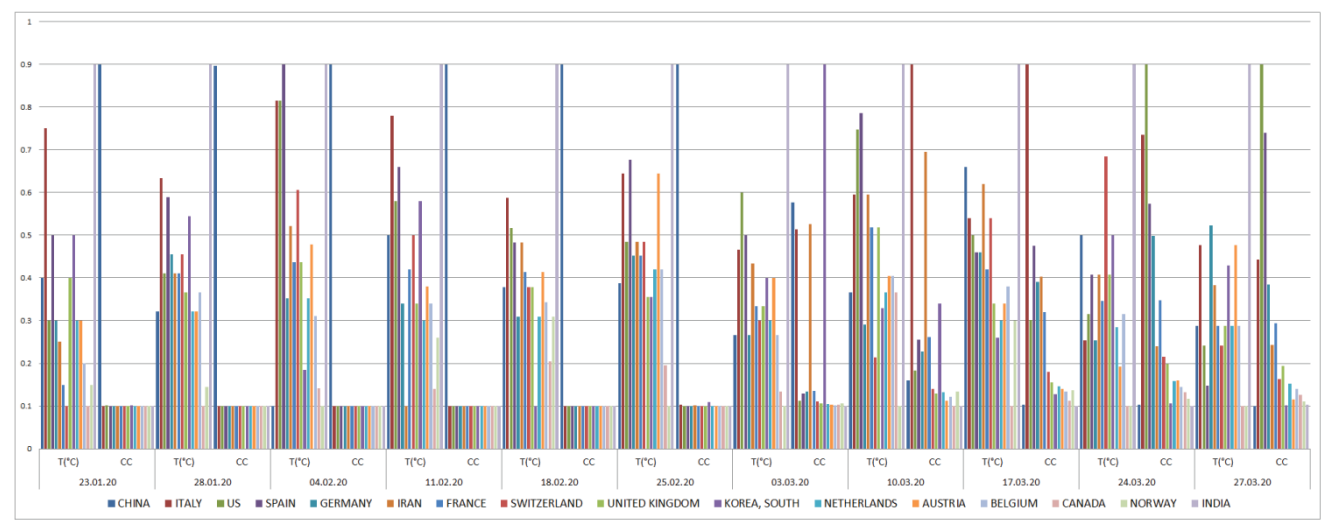

In this paper, we had also considered the number of death cases in these countries year wise taking from January to March and consolidated the data accordingly as (Table 3).

\section{CASE STUDY FOR INDIA COVID-19}

As of $31^{\text {st }}$ January 2020, there are 106 cases confirmed outside china. In India, there is one confirmed cases which reported in Kerala where the patient is returned from Wuhan, China. At this stage 49 samples has been tested out of which 48 were negative. From 30 January to 3 February 2020, there are three confirmed cases in Kerala.

\subsection{Objectives}

In this paper, we had taken the study of temperature of different places within the world and analyse it with the number of COVID-19 patient around the globe and try to analyse the factors responsible for the rise and wide spread of the virus epidemic. This project will also try to analyse the cause and 
Table 3. Number of death cases

\begin{tabular}{|l|l|l|l|l|l|l|l|l|l|l|l|}
\hline Death & 23.01 .20 & 28.01 .20 & 04.02 .20 & 11.02 .20 & 18.02 .20 & 25.02 .20 & 03.03 .20 & 10.03 .20 & 17.03 .20 & 24.03 .20 & 27.03 .20 \\
\hline China & 18 & 131 & 491 & 1112 & 2003 & 2665 & 2947 & 3139 & 3230 & 3281 & 3285 \\
\hline Italy & 0 & 0 & 0 & 0 & 0 & 10 & 79 & 631 & 2503 & 6820 & 7503 \\
\hline US & 0 & 0 & 0 & 0 & 0 & 0 & 7 & 28 & 108 & 706 & 942 \\
\hline Spain & 0 & 0 & 0 & 0 & 0 & 0 & 1 & 35 & 533 & 2808 & 3647 \\
\hline Germany & 0 & 0 & 0 & 0 & 0 & 0 & 0 & 2 & 24 & 157 & 206 \\
\hline Iran & 0 & 0 & 0 & 0 & 0 & 16 & 77 & 291 & 988 & 1934 & 2077 \\
\hline France & 0 & 0 & 0 & 0 & 1 & 1 & 4 & 33 & 149 & 1102 & 1333 \\
\hline Switzerland & 0 & 0 & & 0 & 0 & 0 & 0 & 3 & 27 & 122 & 153 \\
\hline $\begin{array}{l}\text { United } \\
\text { Kingdom }\end{array}$ & 0 & 0 & 0 & 0 & 0 & 0 & 0 & 6 & 56 & 423 & 466 \\
\hline Korea, South & 0 & 0 & 0 & 0 & 0 & 10 & 28 & 54 & 81 & 120 & 126 \\
\hline Netherlands & 0 & 0 & 0 & 0 & 0 & 0 & 0 & 4 & 43 & 277 & 357 \\
\hline Austria & 0 & 0 & 0 & 0 & 0 & 0 & 0 & 0 & 3 & 28 & 30 \\
\hline Belgium & 0 & 0 & 0 & 0 & 0 & 0 & 0 & 0 & 10 & 122 & 178 \\
\hline Canada & 0 & 0 & 0 & 0 & 0 & 0 & 0 & 1 & 5 & 26 & 30 \\
\hline Norway & 0 & 0 & 0 & 0 & 0 & 0 & 0 & 0 & 3 & 12 & 14 \\
\hline India & 0 & 0 & 0 & 0 & 0 & 0 & 0 & 0 & 3 & 10 & 12 \\
\hline
\end{tabular}

environmental and other conditions favouring for the growth and spread of this virus. The study is primary performed with temperature to find out that temperature is really a factor for rise and spread of COVID-19 virus as per the conditions of the countries.

In order to proof the study and working, we had taken the result from 13 states including states from south, north, central, east and west as the demographic conditions vary from north to south and from east to west in terms of temperature. The selected 13 states are most affected states in their region which help us to formulate our result (Figure 3 and Table 4).

Figure 3. COVID 19 infected confirmed cases counts vs. Temperature per day in India state-wide

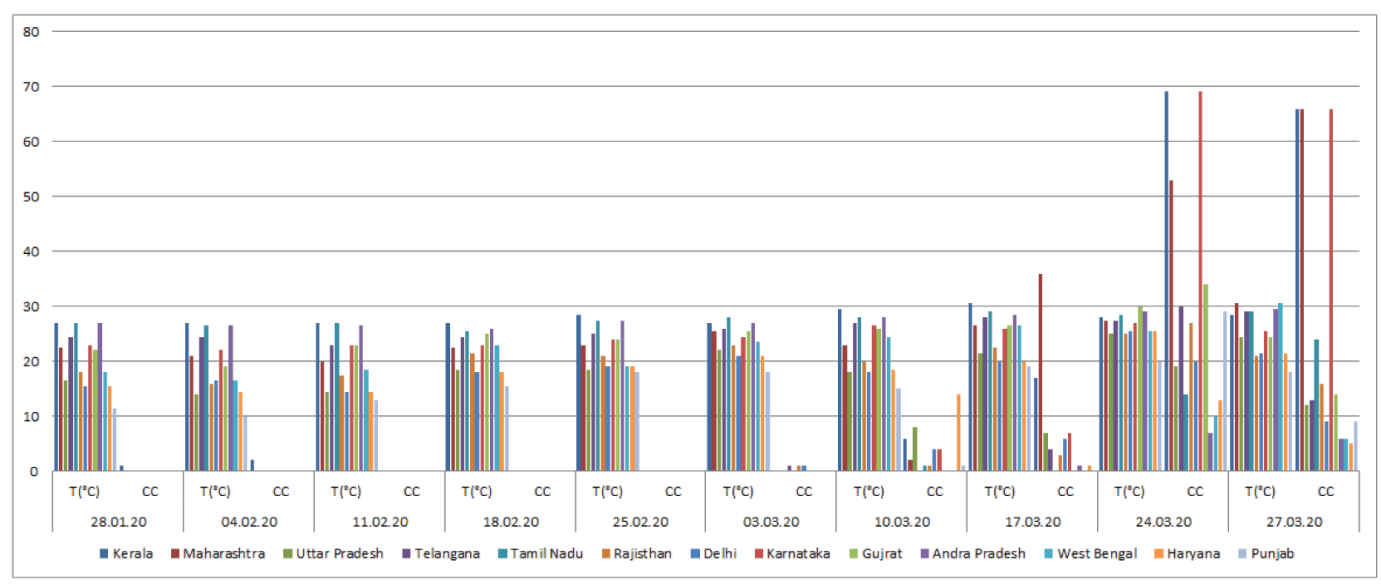


Table 4. Sample data with temperature and COVID 19 confirmed counts per week from January 23, 2020 to March 27, 2020

\begin{tabular}{|c|c|c|c|c|c|c|c|c|c|c|c|c|c|c|}
\hline \multirow{2}{*}{27.03 .20} & $\mathrm{CC}$ & 66 & 66 & 12 & 13 & 24 & 16 & 9 & 66 & 14 & 6 & 6 & 5 & 9 \\
\hline & $\mathrm{T}\left({ }^{\circ} \mathrm{C}\right)$ & 28.5 & 30.5 & 24.5 & 29 & 29 & 21 & 21.5 & 25.5 & 24.5 & 29.5 & 30.5 & 21.5 & 18 \\
\hline \multirow{2}{*}{23.03 .20} & $\mathrm{CC}$ & 69 & 53 & 19 & 30 & 14 & 27 & 20 & 69 & 34 & 7 & 10 & 13 & 29 \\
\hline & $\mathrm{T}\left({ }^{\circ} \mathrm{C}\right)$ & 28 & 27.5 & 25 & 27.5 & 28.5 & 25 & 25.5 & 27 & 30 & 29 & 25.5 & 25.5 & 20 \\
\hline \multirow{2}{*}{17.03 .20} & $\mathrm{CC}$ & 17 & 36 & 7 & 4 & 0 & 3 & 6 & 7 & 0 & 1 & 0 & 1 & 0 \\
\hline & $\mathrm{T}\left({ }^{\circ} \mathrm{C}\right)$ & 30.5 & 26.5 & 21.5 & 28 & 29 & 22.5 & 20 & 26 & 26.5 & 28.5 & 26.5 & 20 & 19 \\
\hline \multirow{2}{*}{10.03 .20} & $\mathrm{CC}$ & 6 & 2 & 8 & 0 & 1 & 1 & 4 & 4 & 0 & 0 & 0 & 14 & 1 \\
\hline & $\mathrm{T}\left({ }^{\circ} \mathrm{C}\right)$ & 29.5 & 23 & 18 & 27 & 28 & 20 & 18 & 26.5 & 26 & 28 & 24.5 & 18.5 & 15 \\
\hline \multirow{2}{*}{03.03 .20} & $\mathrm{CC}$ & 0 & 0 & 0 & 1 & 0 & 1 & 1 & 0 & 0 & 0 & 0 & 0 & 0 \\
\hline & $\mathrm{T}\left({ }^{\circ} \mathrm{C}\right)$ & 27 & 25.5 & 22 & 26 & 28 & 23 & 21 & 24.5 & 25.5 & 27 & 23.5 & 21 & 18 \\
\hline \multirow{2}{*}{25.02 .20} & $\mathrm{CC}$ & 0 & 0 & 0 & 0 & 0 & 0 & 0 & 0 & 0 & 0 & 0 & 0 & 0 \\
\hline & $\mathrm{T}\left({ }^{\circ} \mathrm{C}\right)$ & 28.5 & 23 & 18.5 & 25 & 27.5 & 21 & 19 & 24 & 24 & 27.5 & 19 & 19 & 18 \\
\hline \multirow{2}{*}{18.02 .20} & $\mathrm{CC}$ & 0 & 0 & 0 & 0 & 0 & 0 & 0 & 0 & 0 & 0 & 0 & 0 & 0 \\
\hline & $\mathrm{T}\left({ }^{\circ} \mathrm{C}\right)$ & 27 & 22.5 & 18.5 & 24.5 & 25.5 & 21.5 & 18 & 23 & 25 & 26 & 23 & 18 & 15.5 \\
\hline \multirow{2}{*}{11.02 .20} & $\mathrm{CC}$ & 0 & 0 & 0 & 0 & 0 & 0 & 0 & 0 & 0 & 0 & 0 & 0 & 0 \\
\hline & $\mathrm{T}\left({ }^{\circ} \mathrm{C}\right)$ & 27 & 20 & 14.5 & 23 & 27 & 17.5 & 14.5 & 23 & 23 & 26.5 & 18.5 & 14.5 & 13 \\
\hline \multirow{2}{*}{04.02 .20} & $\mathrm{CC}$ & 2 & 0 & 0 & 0 & 0 & 0 & 0 & 0 & 0 & 0 & 0 & 0 & 0 \\
\hline & $\mathrm{T}\left({ }^{\circ} \mathrm{C}\right)$ & 27 & 21 & 14 & 24.5 & 26.5 & 16 & 16.5 & 22 & 19 & 26.5 & 16.5 & 14.5 & 10 \\
\hline \multirow{2}{*}{28.01 .20} & $\mathrm{CC}^{1}$ & 1 & 0 & 0 & 0 & 0 & 0 & 0 & 0 & 0 & 0 & 0 & 0 & 0 \\
\hline & $\mathrm{T}^{2}\left({ }^{\circ} \mathrm{C}\right)$ & 27 & 22.5 & 16.5 & 24.5 & 27 & 18 & 15.5 & 23 & 22 & 27 & 18 & 15.5 & 11.5 \\
\hline & & 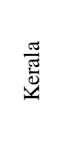 & 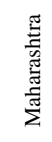 & 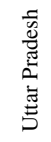 & 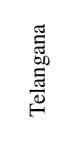 & 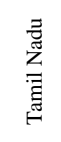 & 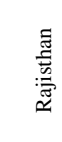 & $\frac{\overrightarrow{\bar{\nabla}}}{\overline{0}}$ & 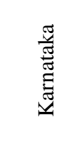 & 莺 & 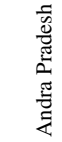 & 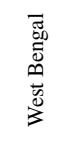 & $\begin{array}{l}\text { 营 } \\
\text { 奇 }\end{array}$ & 莒 \\
\hline
\end{tabular}

\section{RESULTS}

Based on the data analysed above taking the examples of some most affected countries and compare the spread of epidemic during last three month with respect to the temperature parameter we came up with the results shown in Figures 4-8.

In terms of Indian context the relationship between temperature and number of cases variation presented in Figure 2.

\section{CONCLUSION}

The analysis Provides updated information about relationship between COVID-19 and temperature that weather temperature is really one of the parameters which is responsible for increase and rise of COVID-19 epidemic across the globe. The analysis was performed for the month of January, February and March for top 15 countries of the world and also considering the case study of INDIA taking 13 states from different regions in order to establish relationship between COVID-19 virus and temperature. The findings of the result states that temperature is having minor effect on the spread 
Figure 4. Confirmed cases of COVID-19 in different month

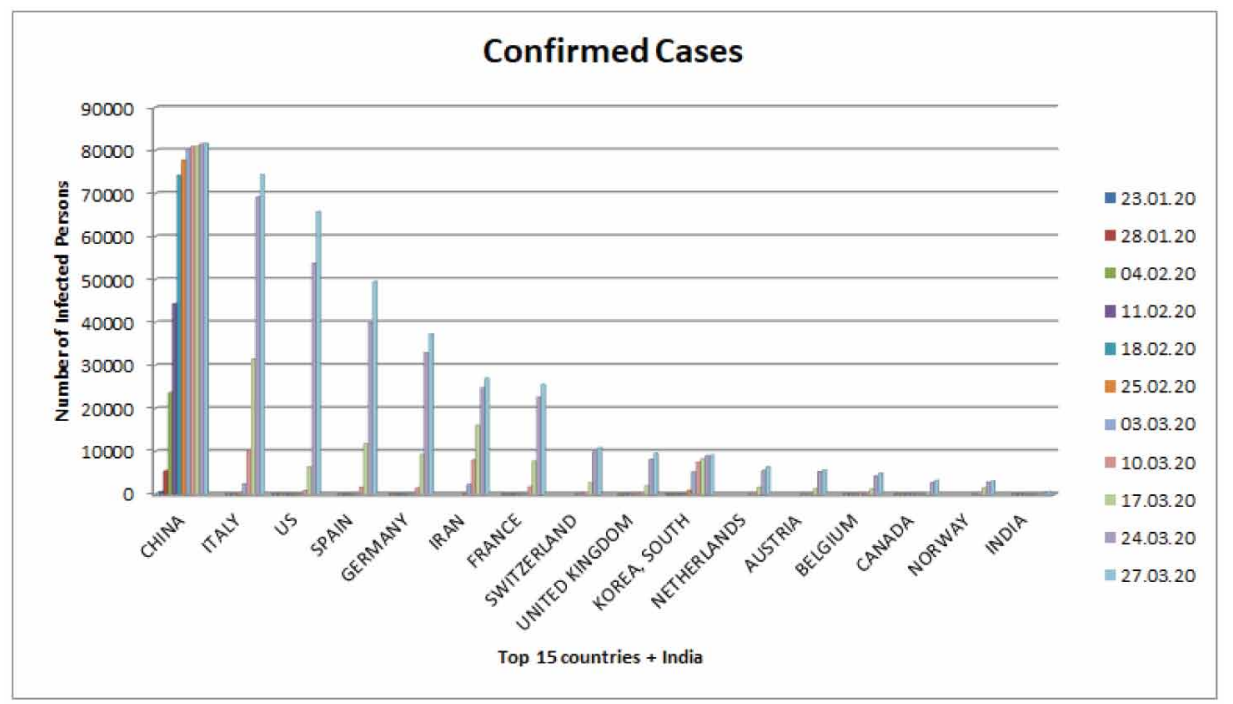

Figure 5. Death due to COVID-19 in different month

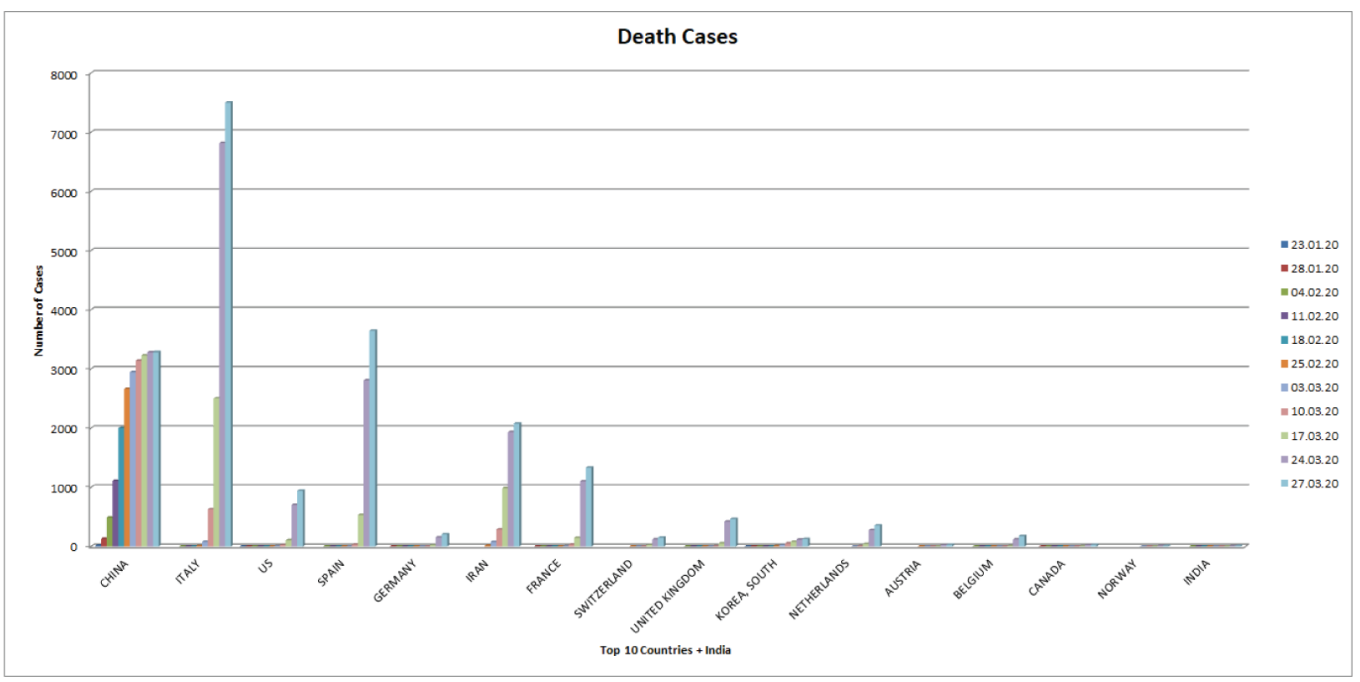

and rise of CORONA virus. There are findings that temperature around $20^{\circ} \mathrm{C}$ to $25^{\circ} \mathrm{C}$ is favouring the survival of COVID-19 virus. Whereas the cold conditions favour the spread of virus and temperature above $27^{\circ} \mathrm{C}$ to $28^{\circ} \mathrm{C}$ is not suitable for the virus spread. 
Figure 6. Temperature and confirmed cases analysis in month of January

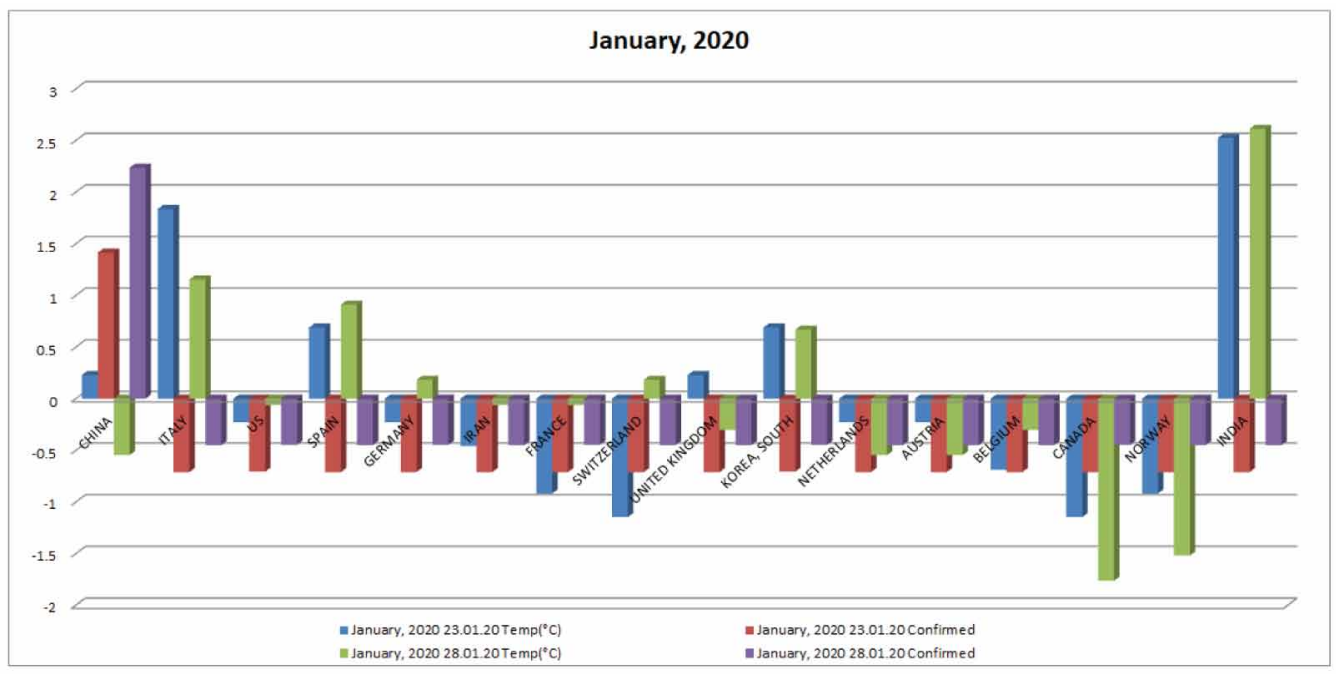

Figure 7. Temperature and confirmed cases analysis in month of February

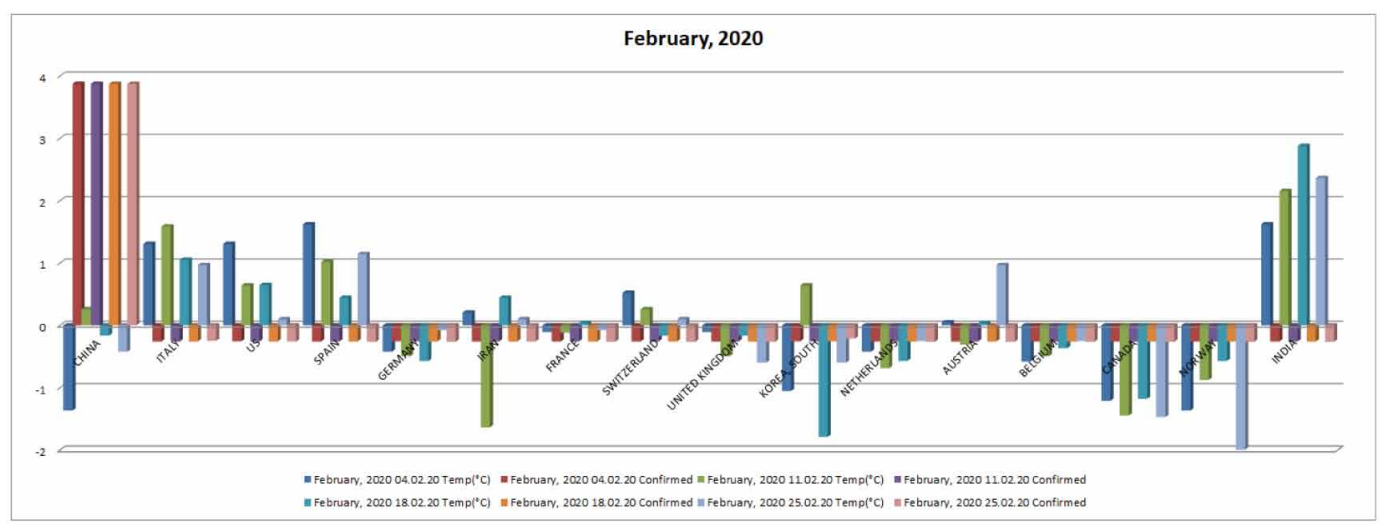

Figure 8. Temperature and confirmed cases analysis in month of March

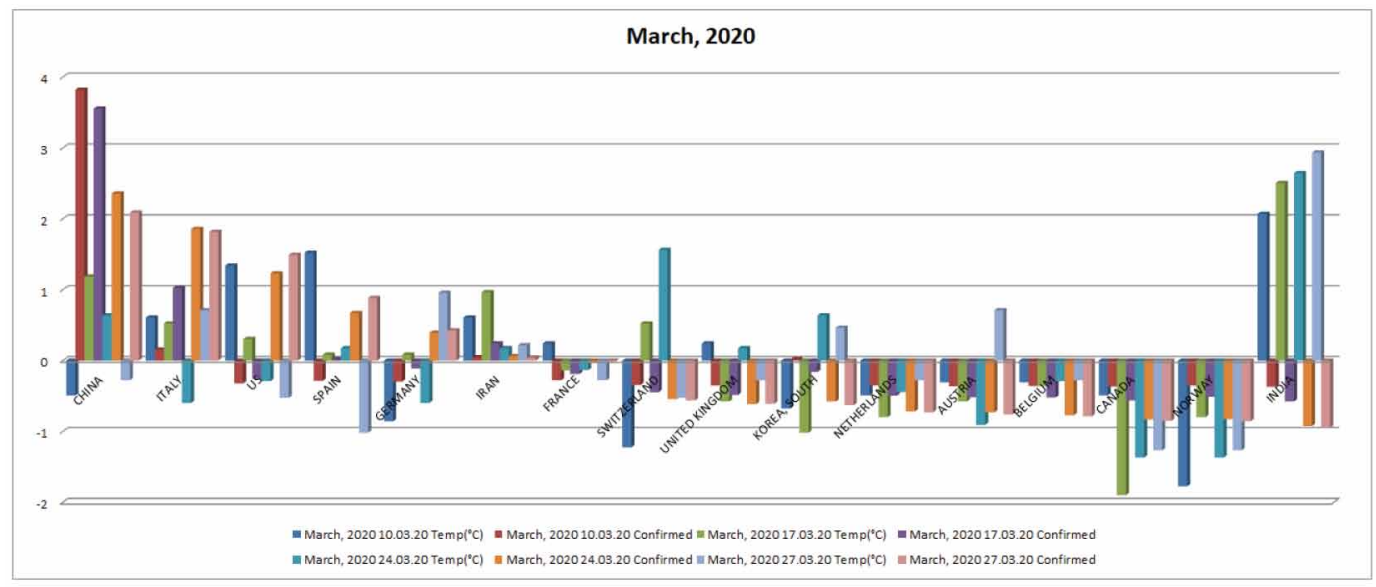




\section{REFERENCES}

Bai, Y., Yao, L., Wei, T., Tian, F., Jin, D. Y., Chen, L., \& Wang, M. (2020). Presumed asymptomatic carrier transmission of COVID-19. JAMA.

Beck, B. R., Shin, B., Choi, Y., Park, S., \& Kang, K. (2020). Predicting commercially available antiviral drugs that may act on the novel coronavirus (2019-nCoV), Wuhan, China through a drug-target interaction deep learning model. bioRxiv.

Chen, Zhou, Dong, Qu, Gong, \& Han. (n.d.). Epidemiological and clinical characteristics of 99 cases of 2019 novel coronavirus pneumonia in Wuhan, China: a descriptive study. Academic Press.

Chen, N., Zhou, M., Dong, X., Qu, J., Gong, F., Han, Y., Qiu, Y., Wang, J., Liu, Y., Wei, Y., Xia, J., Yu, T., Zhang, X., \& Zhang, L. (2020). Epidemiological and clinical characteristics of 99 cases of 2019 novel coronavirus pneumonia in Wuhan, China: A descriptive study. Lancet, 395(10223), 507-513. doi:10.1016/ S0140-6736(20)30211-7 PMID:32007143

Chen, N., Zhou, M., Dong, X., Qu, J., Gong, F., Han, Y., \& Yu, T. et al. (2020). Epidemiological and clinical characteristics of 99 cases of 2019 novel coronavirus pneumonia in Wuhan, China: A descriptive study. Lancet, 395(10223), 507-513. doi:10.1016/S0140-6736(20)30211-7 PMID:32007143

Corman, V. M., Landt, O., Kaiser, M., Molenkamp, R., Meijer, A., Chu, D. K., \& Mulders, D. G. et al. (2020). Detection of 2019 novel coronavirus (2019-nCoV) by real-time RT-PCR. Eurosurveillance, 25(3). Advance online publication. doi:10.2807/1560-7917.ES.2020.25.3.2000045 PMID:31992387

Guan, W. J., Ni, Z. Y., Hu, Y., Liang, W. H., Ou, C. Q., He, J. X., ... Du, B. (2020). Clinical characteristics of 2019 novel coronavirus infection in China. medRxiv. preprint first posted online Feb, 9.

Guan, W. J., Ni, Z. Y., Hu, Y., Liang, W. H., Ou, C. Q., He, J. X., ... Du, B. (2020). Clinical characteristics of 2019 novel coronavirus infection in China. medRxiv. preprint first posted online Feb, 9.

Huang, C., Wang, Y., Li, X., Ren, L., Zhao, J., Hu, Y., \& Cheng, Z. et al. (2020). Clinical features of patients infected with 2019 novel coronavirus in Wuhan, China. Lancet, 395(10223), 497-506. doi:10.1016/S01406736(20)30183-5 PMID:31986264

Kim, J., Shin, J., Lim, Y. H., Honda, Y., Hashizume, M., Guo, Y. L., Kan, H., Yi, S., \& Kim, H. (2016). Comprehensive approach to understand the association between diurnal temperature range and mortality in East Asia. The Science of the Total Environment, 539, 313-321. doi:10.1016/j.scitotenv.2015.08.134 PMID:26363726

Li, M., Zhou, M., Yang, J., Yin, P., Wang, B., \& Liu, Q. (2019). Temperature, temperature extremes, and causespecific respiratory mortality in China: A multi-city time series analysis. Air Quality, Atmosphere \& Health, 12(5), 539-548. doi:10.1007/s11869-019-00670-3

Novel, C. P. E. R. E. (2020). The epidemiological characteristics of an outbreak of 2019 novel coronavirus diseases (COVID-19) in China. Zhonghua liu xing bing xue za zhi= Zhonghua liuxingbingxue zazhi, 41(2), 145.

Read, J.M., Bridgen, J.R.E., Cummings, D.A.T., Ho, A., \& Jewell, C.P. (2020). Novel coronavirus 2019$n C o V$ : early estimation of epidemiological parameters and epidemic predictions. medRxiv 2020. doi: $.10 .1101 / 2020.01 .23 .20018549$

Steel, J., Palese, P., \& Lowen, A. C. (2011). Transmission of a 2009 pandemic influenza virus shows a sensitivity to temperature and humidity similar to that of an H3N2 seasonal strain. Journal of Virology, 85(3), 1400-1402. doi:10.1128/JVI.02186-10 PMID:21084485

Wang, D., Hu, B., Hu, C., Zhu, F., Liu, X., Zhang, J., \& Zhao, Y. (2020). Clinical characteristics of 138 hospitalized patients with 2019 novel coronavirus-infected pneumonia in Wuhan. Jama. doi:10.1001/jama.2020.1585

Wang, P., Lu, J., Jin, Y., Zhu, M., Wang, L., \& Chen, S. (2020). Epidemiological characteristics of 1212 COVID-19 patients in Henan, China. medRxiv.

WHO. (n.d.). https://www.who.int/docs/default-source/coronaviruse/situation-reports/20200221-sitrep-32covid-19.pdf?sfvrsn\&equals;4802d089_2 


\section{ENDNOTES}

COVID 19 Confirmed Cases (CC) counts.

Temperature.

Parag Verma is working as Assistant Professor at Uttaranchal University, Dehradun. He is having a long experience of $8+$ years in the field of industry and academics. He is having 15+ international papers in reputed conferences and journals. He has contributed 2 books with publishers like Nerosa and Alpha, and currently working on 2 more accepted books. He had also contributed 4 chapters for reputed publishers. He is also an editorial board member of many reputed conferences and journals including Scopus. He is also a guest editor of IJNCDS (Scopus Indexed Inderscience Journal) and many more. He is associated with many societies and organizations for the welfare of educationalist societies.

Ankur Dumka $(P h D)$ is working as Associate Professor in Graphic Era Deemed to be University, Dehradun. He is having a long experience of 10+ years in the field of industry and academics. He is associated with smart city Dehradun as an academic expert committee member and co-ordinator in terms of projects related to IT. He is having $50+$ international papers in reputed conferences and journals. He has contributed 3 books with publishers like Taylor and Francis, IGI global, etc. and currently working on 3 more accepted books. He had also contributed 14 chapters for reputed publishers. He is also editorial board members of many reputed conferences and journals including Scopus and IEEE. He is also a guest editor of IJNCDS (Scopus Indexed Inderscience Journal), guest editor for IJNCR (ACM digital library -IGI global journal) and many more. He is associated with many societies and organizations for the welfare of educationalist societies.

Anuj Bhardwaj, M. Tech. \& Ph.D degree in computer science. He is currently a Professor of Computer Science \& Engineering with Chandigarh University, Mohali, Punjab. He is having a long experience of 12+ years in the field of industry and academics. He is having 27+ international papers in reputed conferences and journals. He has contributed 2 books with publishers like Nerosa and Alpha, and currently working on 2 more accepted books. He had also contributed 6 chapters for reputed publishers. His current research interests include pattern \& character recognition, graphics \& vision, artificial intelligence \& neural networks and machine learning.

Alaknanda Ashok (PhD) is working as Dean \& Professor, College of Technology, G.B.Pant University of Agriculture and Technology, Pantnagar, did her PhD in digital image processing. She is having more then 23 yrs of work experience, having administrative work experience as Director, Women Institute of Technology, Dehradun and Controller of Examinations of Uttarakhand Technical University, along with teaching and research work. She worked/ supervised number of projects as senior Senior Principal Scientist in Council of Scientific and Research (CSIR), Organization for 4 yrs. She is having more than 50 research papers in reputed journals and conferences of repute . She is guiding PhD students in the field of digital image processing, renewal energy, IOT, ANN, electrical systems etc. She is having 3 patent published. She is supervising number of research projects of MHRD-world bank. She is also having many book chapters and currently working on proposed books with taylor and francis. She is also associated with many journals and conferences in the capacity of editor, editorial board member and convener. Organised \& participated in number of conferences and workshops. she is a keep sport person - actively participate in various sports activities and Associated with number of sports and welfare Organization.

Mukesh Chandra Kestwal did M.Tech in 2014 Government Engineering College on MHRD Fellowship. He has worked for 2 years with Uttarakhand State Council for Science and Technology (Govt. of Uttarakhand) and 3 years with University of Petroleum and Energy Studies Dehradun on DST Funded projects. To his credentials, he is having a total of 6+ entrepreneurial experience in Research and Innovation, 2 patents, 6 International Conference Paper, have supported multiple events and conference and have been supporting many startups as Business and Technical mentors. He has actively supported 20+ business startups, events and projects from Government as well as Private organisation.

Praveen Kumar, Founder and Director of Yuvayana Tech and Craft Pvt. Ltd. He did Master of Technology in Robotics Engineering. He has 5+ year of experience in innovative technology, automation and robotics. He is having 8+ year of experience in designing and modeling PCB designing. He completed several projects such as low cost PCB design etc. as vendor for various automation companies. Currently he is associated with Yuvayana as director which is a recognized startup \& innovative company in India, which deals with artificial intelligence (AI) and deep learning-based online software solution provider. He conducted several workshops on the online educational platforms, digital marketing, and freelance projects to provide digital education for the students. 